\title{
POSITIVE AND NEGATIVE ROUGHNESS ACCORDING TO LOCAL DIFFERENCES BETWEEN DEM SURFACE AND 3D REFERENCE PLANES
}

\author{
Jean-François Parrot ${ }^{1 *}$, Carolina Ramírez-Núñez ${ }^{2}$ \\ ${ }^{1}$ Laboratorio de Análisis Geoespacial (LAGE), Instituto de Geografía, UNAM, Ciudad de México, México - parrot@igg.unam.mx \\ ${ }^{2}$ ENCiT, UNAM, Ciudad de México, México
}

Commission III/7

KEY WORDS: Local roughness, global roughness, Digital Elevation Models, tri-dimensional plane of reference, reference plane orientation.

\begin{abstract}
:
The irregularities of the earth's surface are quantified by means of roughness measurements using Digital Elevation Models (DEM's). This article presents a roughness measurement method that is based on the calculation of the difference of altitude existing between a plane passing through the centre of a moving window and the altitude of the DEM surface inside this window. This method differs from the measure of the standard deviation and best fit plane, in the sense that it considers all difference values, positives or negatives. The measurement is done in a $3 \times 3$ or a $5 \times 5$ moving window and contemplates inside this window the plane which passes through the centre of the window and the highest pixel located in the border or perimeter of this window. According to the 3D configuration of the DEM surface inside the moving window, the sum of all the differences is positive or negative, allowing to discriminate the local morphology independently of the global roughness. The roughness variable which distinguishes negative and positive values allows to classify accurately landscape units such as watersheds, riverbeds, volcanic assemblages as well as landforms associated with tectonic structures.
\end{abstract}

\section{INTRODUCTION}

The notion of roughness is commonly used in quantitative geomorphology studies. This variable characterizes rock types, performs relief classifications, identifies landslide mechanisms, among others (Barnett et al., 2004, Berti et al., 2013). The roughness extracted from a Digital Elevation Model (DEM) is defined in terms of the variability of the elevation data. The main extraction methods are the root mean square applied to elevation and slope grids (Grohman, 2015), eigenvalue ratios (Cloude, 1999; Cloude et al., 2000), structuring elements (Cao et al., 2015), fractal dimension (Taud and Parrot, 2005), discrete Fourier transform (Bingham and Siegert, 2009), continuous wavelet transform and wavelet lifting scheme (Hani et al., 2011, 2012), as well as standard deviation in a fit plane (Hobson, 1972; Evans, 1972; Herzfeld et al., 2000; Haneberg et al., 2005,). The results of these measurements depend on the resolution of the DEM and the size of the moving window (Grohmann et al., 2011).

Surface roughness describes elevation variations over a particular scale (Grohmann and Hargitai, 2014, Grohman et al., 2015). To define the relationships existing between distinct curvature and various roughness characteristics, Hani et al. $(2011,2012)$ proposed to compute individually all the cells describing a Digital Elevation Model (DEM) and then realize a multiscale analysis. Their research showed that large scale surface roughness can be characterized using the distribution of slope frequencies, but a size increasing of the moving window generally used to measure roughness parameter is not particularly beneficial and in fact small pixels and small moving windows better reveals the surface condition. Regarding altitude acquisition techniques, the parameterization of radar data often

\footnotetext{
* Corresponding author
}

uses the root mean square (RMS) of slopes (Aharonson et al. 1998), but when it comes to laser altimetry sets, the absolute value of median slope is sufficient and provides a better characterization of surface slopes (Kreslavsky and Head, 1999). In fact, the roughness is generally considered as a geomorphological landform component, but landforms are often represented in heterogeneous thematic maps (De Reu et al., 2013; Melelli et al., 2017). For this reason, a numerical assessment provides a better quantitative characterization of a discretized space represented by continuous and regular cells, as it is the case for rasterized DEM.

However, in this research, it is proposed to generate a threedimensional plane from the real altitude values in each window size considering not only the altitude deviation, but also the direction of the reference planes. The results of the algorithm are compared considering 1$)$ two sizes of moving window $(3 \times 3$ and $5 \times 5$ ), 2) two different resolutions of DEM and 3) two roughness measurement methods providing results comparable to the best fit plane method: the three-dimensional fractal measurement (Taud and Parrot, 2005) and the calculation of the threedimensional surface (Parrot, 2007).

\section{STUDY AREA AND DATA USED}

\subsection{Study area}

The study area is in the southern limit of the Trans-Mexican Volcanic Belt (TMVB), to the east of the state of Michoacán, in the central region of Mexico. This region corresponds to a transition zone between Oligocene (Sierra Madre Occidental) and Miocene to Quaternary volcanism (TMVB) (Blatter and Carmichael, 1998) that overlies Jurassic schists and Cretaceous 
limestones, marls, and shales of the Balsas River depression (Petersen, 1989; McLeod, 1989) (Fig. 1).

In the central area, the Tuxpan river runs in a tectonic control canyon in a north-south direction, and when it finds the transition from volcanic to sedimentary rocks, it quickly deepens its channel (Fig. 2). The volcanic rocks to the northeast correspond to quaternary basaltic volcanism forming shield volcanoes. The northwest region is a mountainous relief mainly formed by dacite from the Neogene (Siebe et al., 2007).

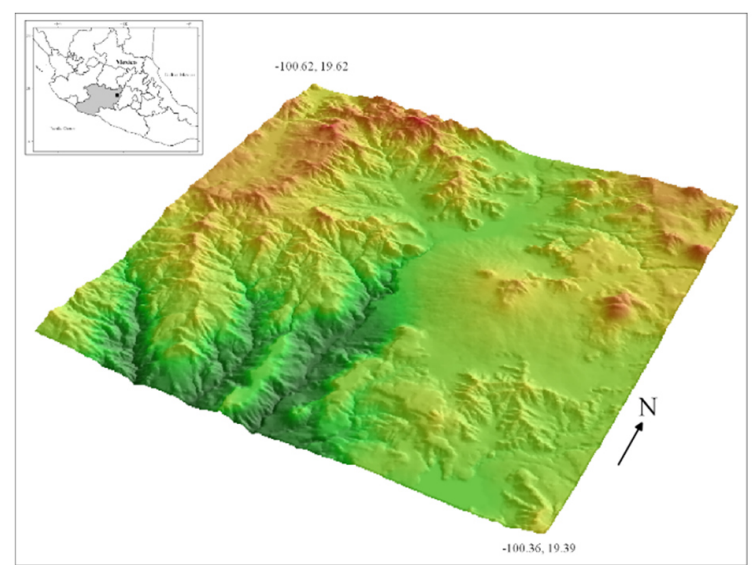

Figure 1. Situation map and block of the study area.

Underlying this unit, to the southwest, Paleogene rhyolitic rocks with oligomictic conglomerates form a mountainous range in the direction of the Balsas depression. Finally, to the southeast, are the limestone rocks and oligomictic conglomerates of the Upper Cretaceous, as well as sandstones-shales also from the Cretaceous (SGM, 1998).

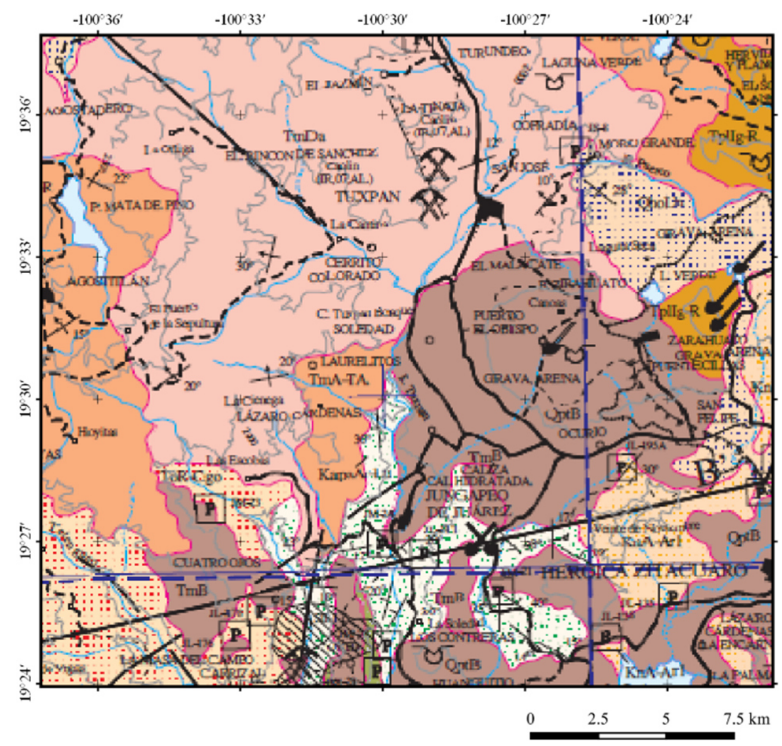

Figure 2. Geological map (SGM, 1998).

\subsection{Data used}

Data used correspond to Digital Elevation Models (Fig. 3) with resolution of 5 and $20 \mathrm{~m}$ generated by means of the interpolation of vector data (INEGI, 2015) using contour lines dilation method (Taud et al., 1999).

\section{METHOD}

\subsection{Overview}

The method presented here is based on the difference of altitude existing between a plane passing through the centre of a moving window and the altitude of the DEM surface inside this window. This method differs from the measure of the standard deviation and best fit plane, in the sense that it considers all difference values, positives or negatives.

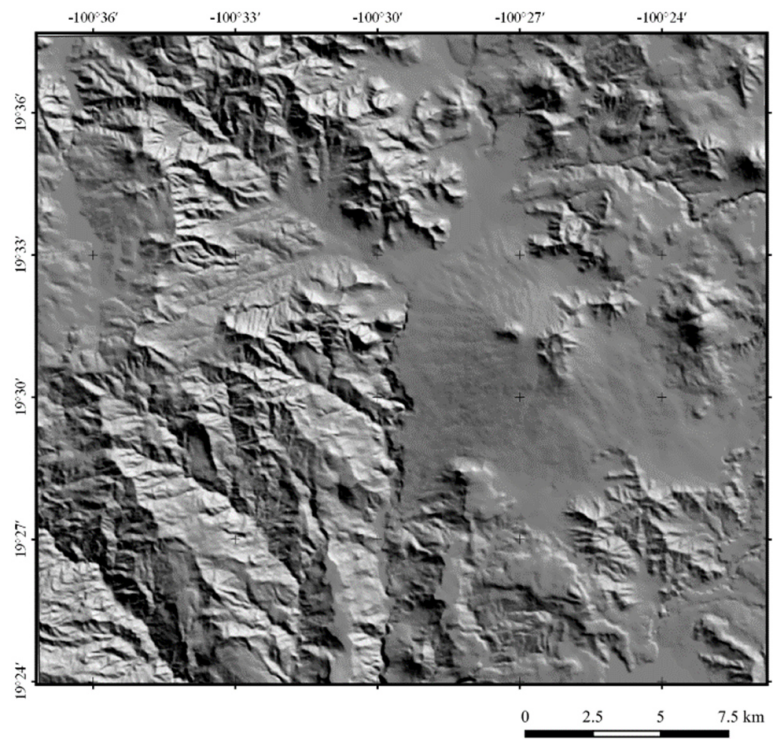

Figure 3. Shadowed Digital Elevation Model.

The measurement of these differences is realized in a $3 \times 3$ or a $5 \times 5$ moving window and contemplates inside this window the plane which passes through the centre of the window and the highest pixel located in the border or perimeter of the window (Fig. 4).

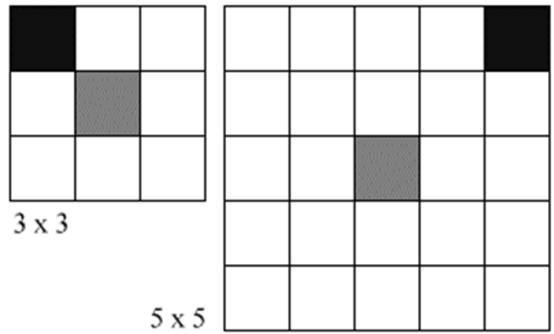

Figure 4. Example of position of the highest value (black) in a 3 $\times 3$ and $5 \times 5$ moving window. Centre of the window in grey.

The calculation considers the difference between the altitude values of each pixel of this plane and the altitude values of each corresponding pixel of the DEM in the moving window and the sum of these differences allows characterizing the level of roughness of the local studied surface.

Depending on the result, it is possible to differentiate three classes: the first groups the positive values of the sum, the second 
those which are negative, and the third group located in the centre of the histogram correspond to flat areas whatever the value of the slope.

\subsection{Treatments}

Inside the moving window, the algorithm first searches, comparing the altitude of the window centre, the highest elevation located on the edge of the window and calculates the difference between the two altitudes. The second step locates the position of this maximum to define the code used to generate the reference plane in the three-dimensional space.

As presented in the figure 5,8 codes are attributed according to the position of the highest border point: code 1 for the NW, code 2 for the North, code 4 for the NE, code 8 for the East, code 16 for the SE, code 32 for the South, code 64 for the SW and code 128 for the West. This codification used here by analogy, is generally employed to define the configuration of the pixel assemblage surrounding the central pixel of a moving window (Tarboton, 1997; Jenson and Domingue, 1988).

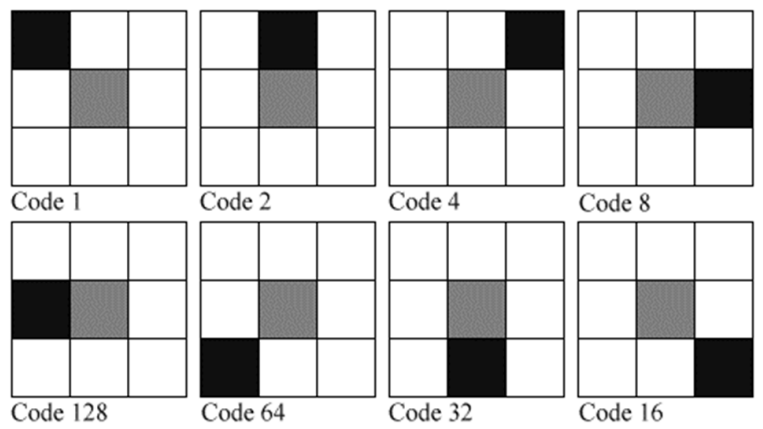

Figure 5. Code according to the position of the highest value (Gray tone: central pixel of altitude $A_{C}$; in black, highest pixel of altitude $A_{H}$ ).

The same codes and the same cardinal positions are used in the case of a $5 \times 5$ moving window, that means that 8 intermediary positions in the border are neglected, but this restriction does not affect the validity of the result.

A quite simple generation of the plan of reference is as follows: the difference of altitude $D$ between the altitude $A_{C}$ of the central point and the highest altitude value $A_{H}$ is considered as well as the code. In the case of a $3 \times 3$ moving window, three difference values are added or subtracted to the central pixel value to generate the plane of reference. In the case of a $5 \times 5$ window, 5 difference values are required to produce the plane of reference. Figure 6 provides all the patterns used to define the plane in a 3 $\times 3$ window. In this figure, $D$ corresponds to the value of difference added to $A_{C}, D / 2$ is the half of the difference added to $A_{C}, d$ and $d / 2$ are negative values that correspond to the quantity subtracted to $A_{C}, 0$ means unchanged $A_{C}$ value.

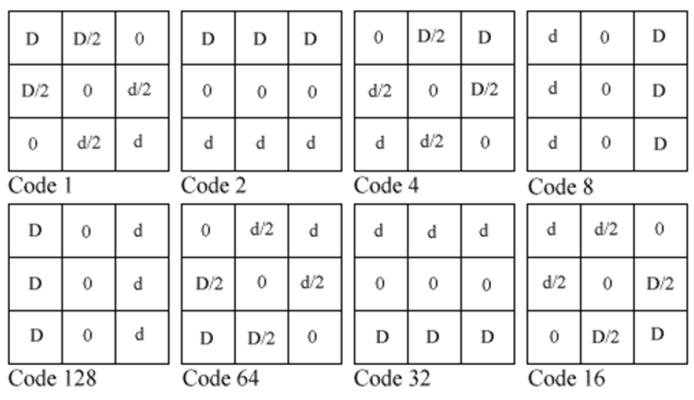

Figure 6. Patterns according to the code.

Figure 7 concerns two examples of pattern configuration in the case of a $5 \times 5$ moving window. In this case, $D$ corresponds also to the value of difference added to $A_{C}, 3 D / 4$ is equal to $D \times 0.75$, $D / 2$ to $D \times 0.5$ and $D / 4$ to $D \times 0.25$; as previously $d, 3 d / 4, d / 2$, and $d / 4$ are negative values.

\begin{tabular}{|c|c|c|c|c|}
\hline $\mathrm{D}$ & $3 \mathrm{D} / 4$ & $\mathrm{D} / 2$ & $\mathrm{D} / 4$ & 0 \\
\hline $3 \mathrm{D} / 4$ & $\mathrm{D} / 2$ & $\mathrm{D} / 4$ & 0 & $\mathrm{~d} / 4$ \\
\hline $\mathrm{D} / 2$ & $\mathrm{D} / 4$ & 0 & $\mathrm{~d} / 4$ & $\mathrm{~d} / 2$ \\
\hline $\mathrm{D} / 4$ & 0 & $\mathrm{~d} / 4$ & $\mathrm{~d} / 2$ & $3 \mathrm{~d} / 4$ \\
\hline 0 & $\mathrm{~d} / 4$ & $\mathrm{~d} / 2$ & $3 \mathrm{~d} / 4$ & $\mathrm{~d}$ \\
\hline
\end{tabular}

\begin{tabular}{|c|c|c|c|c|}
\hline $\mathrm{D}$ & $\mathrm{D}$ & $\mathrm{D}$ & $\mathrm{D}$ & $\mathrm{D}$ \\
\hline $\mathrm{D} / 2$ & $\mathrm{D} / 2$ & $\mathrm{D} / 2$ & $\mathrm{D} / 2$ & $\mathrm{D} / 2$ \\
\hline 0 & 0 & 0 & 0 & 0 \\
\hline $\mathrm{d} / 2$ & $\mathrm{~d} / 2$ & $\mathrm{~d} / 2$ & $\mathrm{~d} / 2$ & $\mathrm{~d} / 2$ \\
\hline $\mathrm{d}$ & $\mathrm{d}$ & $\mathrm{d}$ & $\mathrm{d}$ & $\mathrm{d}$ \\
\hline
\end{tabular}

Figure 7. Patterns according to the code 1 and 2 in a $5 \times 5$ moving window.

The sum of the differences within the moving window corresponds to a measure of the surface roughness that can be expressed in the following way:

$$
R_{(i, j)}=\sum_{\substack{i-m \\ j-m}}^{\substack{j+m \\ j+m}} A_{s_{(i, j)}}-A_{p_{(i, j)}}
$$

where $R_{(i, j)}$ is the local roughness of the pixel which coordinates are $i$ and $j$ ( $i$ for the lines and $j$ for the columns); $A_{s}$ is the altitude of the DEM and $A_{p}$ the altitude of the reference plan in the same point, and $m$ represents the window range. The range $m$ allows defining the size $w s$ of the window side according to the formula: $w s=(m \times 2)+1$.

When sometimes, the central pixel corresponds to the greatest hypsometric value, the reference plane is horizontal, and its altitude corresponds to the altitude of the central pixel. In this case the sum of all the negative differences will be evidently negative.

The frequency of the resulting roughness values is reported in a pyramid curve (Fig. 8). The roughness values between a lower value $R_{\text {low }}$ (in the example of treatment (resolution 5; moving window $3 \times 3$ ) shown in figure $10, R_{\text {low }}$ is equal to -32.52 ) and 0 are normalized between 0 and 128 and values comprised between 0 and an upper value $R_{u p}$ (25.56 in the same example) are normalized between 128 and a maximum normalized value $N_{\max }$ according to the following formula when $R_{u p}$ is lower than $R_{\text {low: }}$

$$
N_{\text {max }}=\left[\left(128 /\left|R_{\text {low }}\right|\right) \times R_{\text {up }}\right]+128
$$


in the present example, $N_{\max }$ is 228 .

An inverse calculation is done when $R_{u p}$ is greater than $R_{l o w}$.

In the case of the figure 9 that corresponds to a treatment applied to a DEM with a resolution of 20 meters and a moving window 5 $\times 5, R_{\text {low }}$ is equal to -371.98 and $R_{u p}$ is 343.23 .

Afterwards, a lateral and symmetrical stretching is applied to visualized better the results (Fig. 9 and Fig. 10).

The minimum value of the curve corresponds to crest lines and the maximum values to riverbeds. The highest point of the curve represents zones corresponding to a plane whatever the value of the slope (Fig. 8).
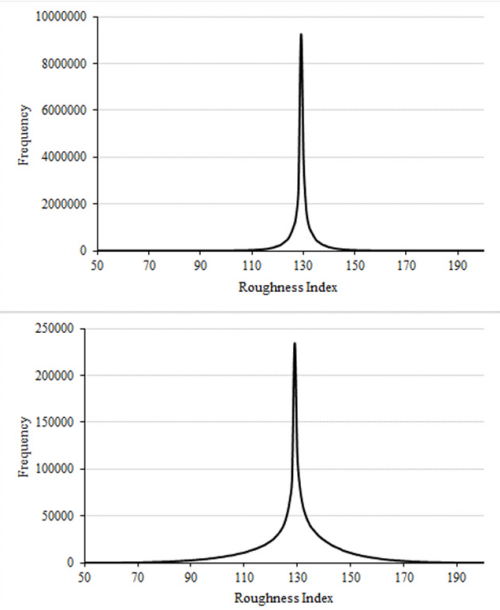

B

Figure 8. Histograms. A. DEM 5 meters moving window $3 \times 3$; B. DEM 20 meters moving window $5 \times 5$.

\section{RESULTS AND DISCUSSION}

We present two results here: the first one (Fig. 9) corresponds to a treatment applied to a DEM with a horizontal resolution of 20 meters and a calculation using a $5 \times 5$ moving window; the second (Fig. 10) is the result of a processing applied to a DEM with a resolution of 5 meters using a $3 \times 3$ moving window.

The process presented in this paper corresponds mainly to a textural treatment that emphasizes the structural features. For instance, the detail reported in the figure 11, clearly shows the position of the riverbed and the thalweg between the two lateral escarpments corresponding to the border of the fluvial terrace.

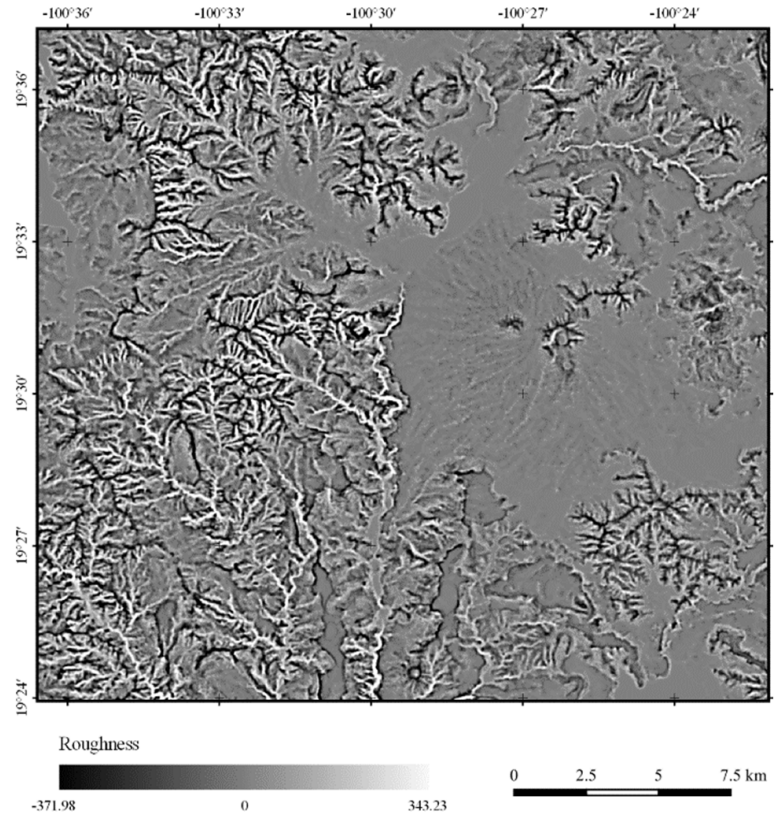

Figure 9. Stretched image corresponding to DEM with $20 \mathrm{~m}$ resolution and $5 \times 5$ moving window.

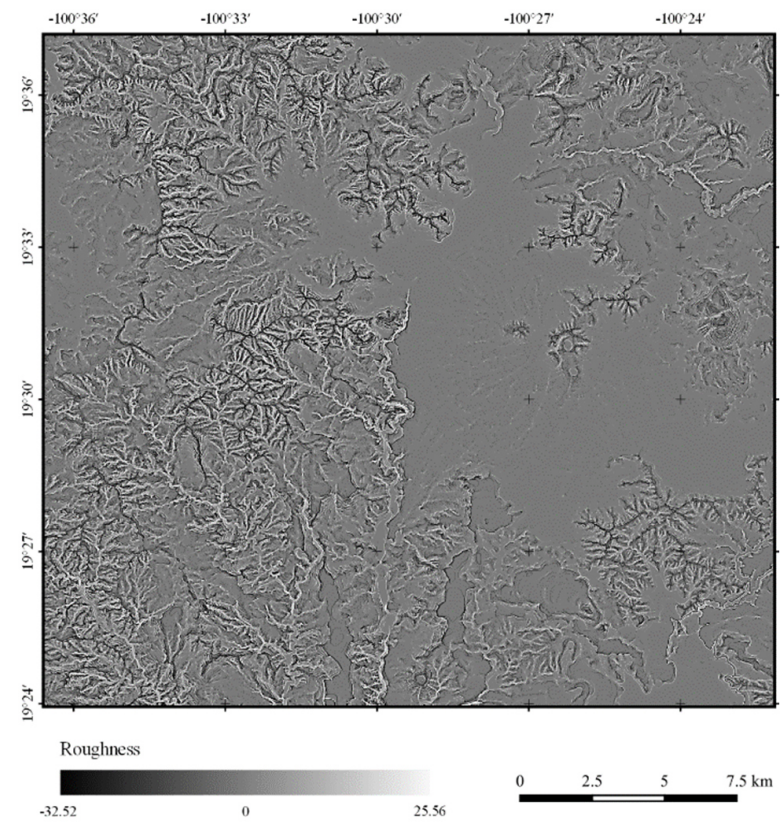

Figure 10. Stretched image corresponding to DEM with $5 \mathrm{~m}$ resolution and $3 \times 3$ moving window.

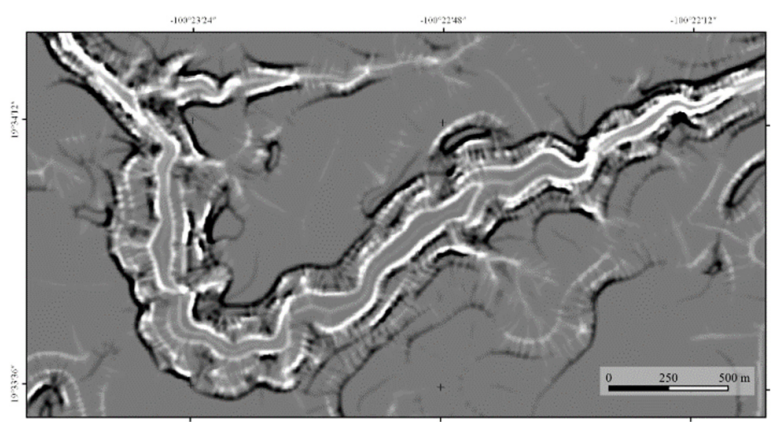


Figure 11. Edges of the riverbed and terrace borders.

The distinction between various structural features results from the disjunction of the differences between the DEM surface and the reference plane as it has been previously defined. Thus, a textural factor can behave like a structural tool.

It should be noted that if we add the absolute values as shown in the following formula, we obtain a result comparable to that proposed for example by Hani et al. (2012) who estimates that the roughness can be considered as an expression of the vertical deviations by using the original surface and the surface of best fit whether based on all the curved subregions inside the moving window of observation or limited to only flat subregions.

$$
R_{(i, j)}=\sum_{\substack{i-m \\ j-m}}^{i+m}\left|A_{s_{(i, j)}}-A_{p_{(i, j)}}\right|
$$

In this case, as shown in figure 12, the representation of roughness is expressed globally and does not reveal the structural elements which determine it.

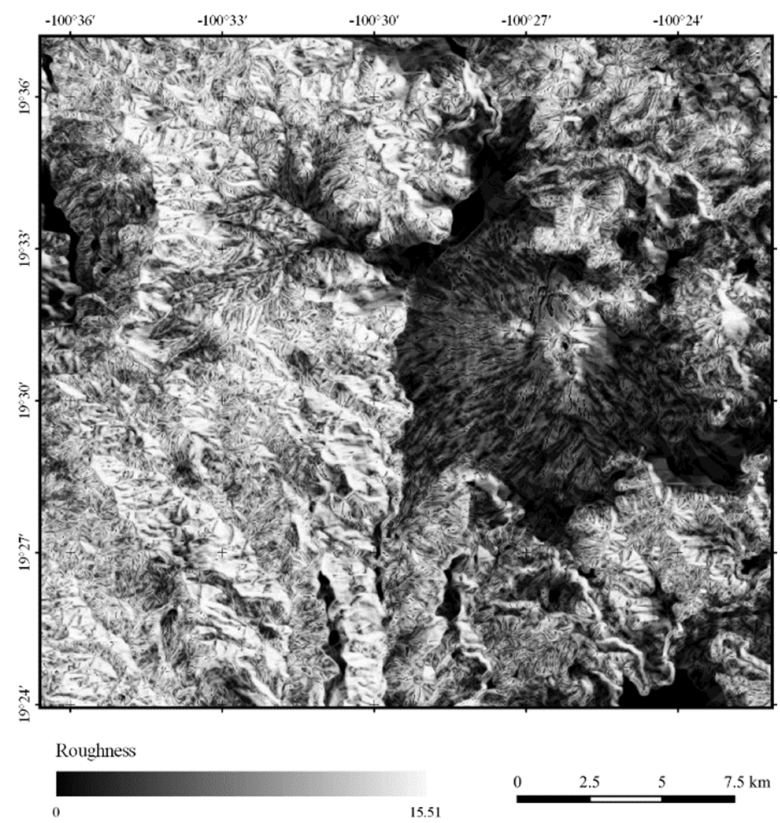

Figure 12. Stretched image of the global treatment applied to a DEM with a $20 \mathrm{~m}$ resolution and a $5 \times 5$ moving window.

\section{CONCLUSION}

In fact, whether they are results coming from the global calculation or from calculations which differentiate negative values and positive values, areas with high roughness are easily defined. It must be noted, as shown in figure 13, that the most acute crest lines (values between 0 and 110 on the histogram of figure 8B) and the deepest valleys (values between 145 and 255 on the same histogram) are found in the same areas with strong roughness.

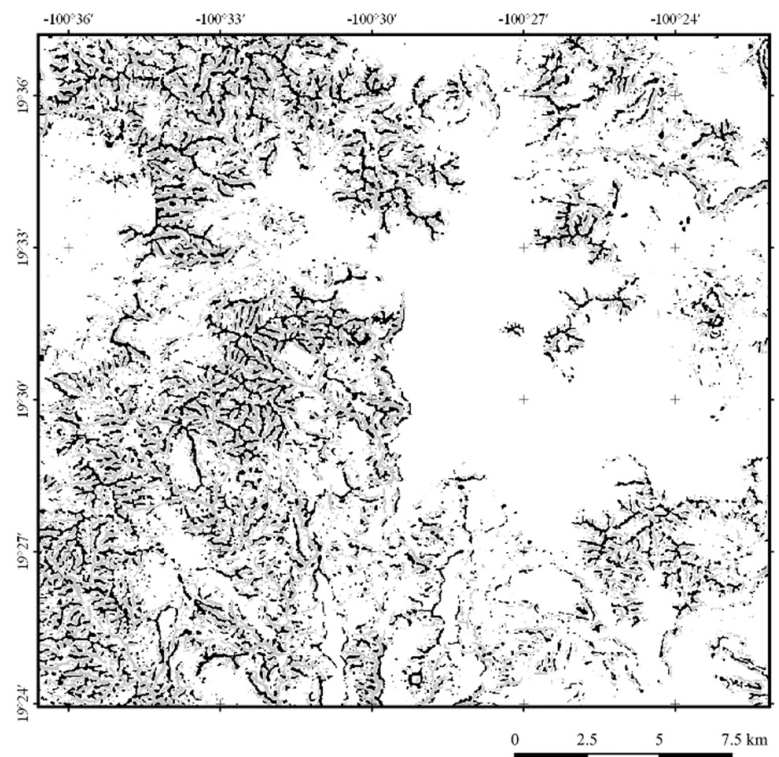

Figure 13. Black crest lines (0-110) and grey riverbeds (145-255) inside roughness zones.

It is also possible to extract the areas of low roughness by thresholding the values which correspond to the peak of the histogram (123 to 133). In figure 14, these zones appear in grey on which the weak slope zones $\left(0\right.$ to $\left.4^{\circ}\right)$ have been plotted in black. In this image, a basaltic volcanic cone is well individualized (low roughness, slopes greater than $4^{\circ}$ ).

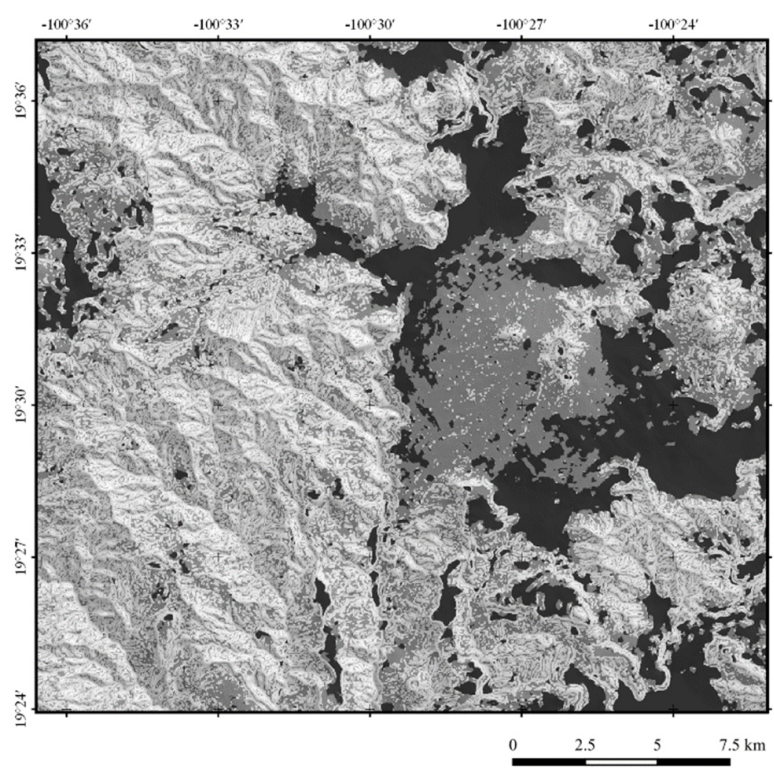

Figure 14. Light grey: Low roughness regions with a slope greater than $4^{\circ}$ : dark grey: Low roughness regions with a slope lower than $4^{\circ}$.

Moreover, the results obtained by using the notion of deviation from the plane passing through the centre of the moving window and the highest point of the perimeter of this window can be compared to those obtained using the three-dimensional fractal measurement (Taud and Parrot, 2005) (Fig. 15) and the calculation of the three-dimensional surface (Parrot, 2007; Parrot and Ramírez-Núñez, 2020) (Fig. 16). 


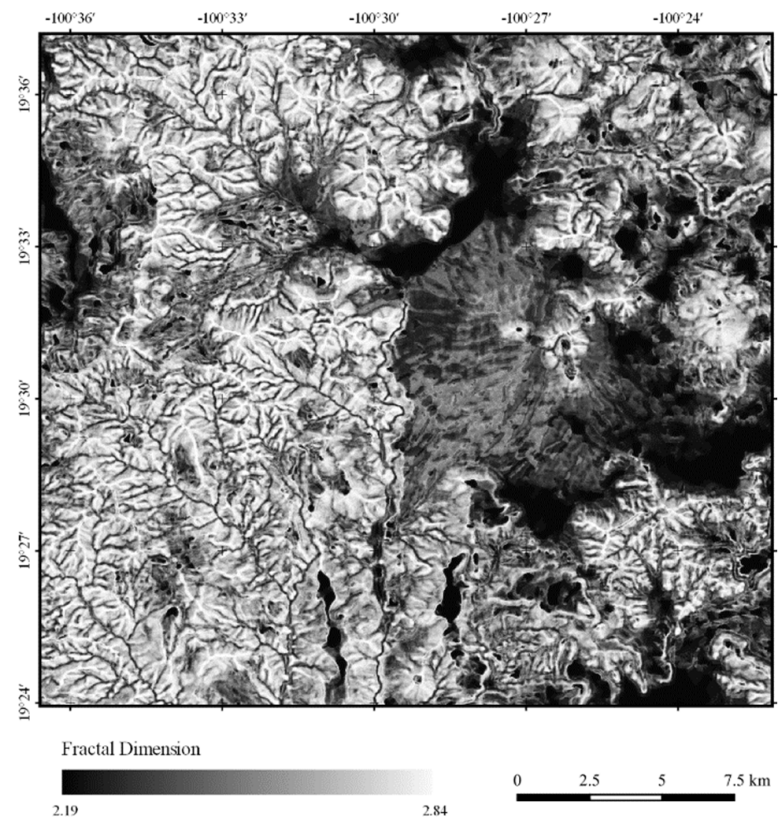

Figure 15. Fractal dimension applied to the DEM (20 m).

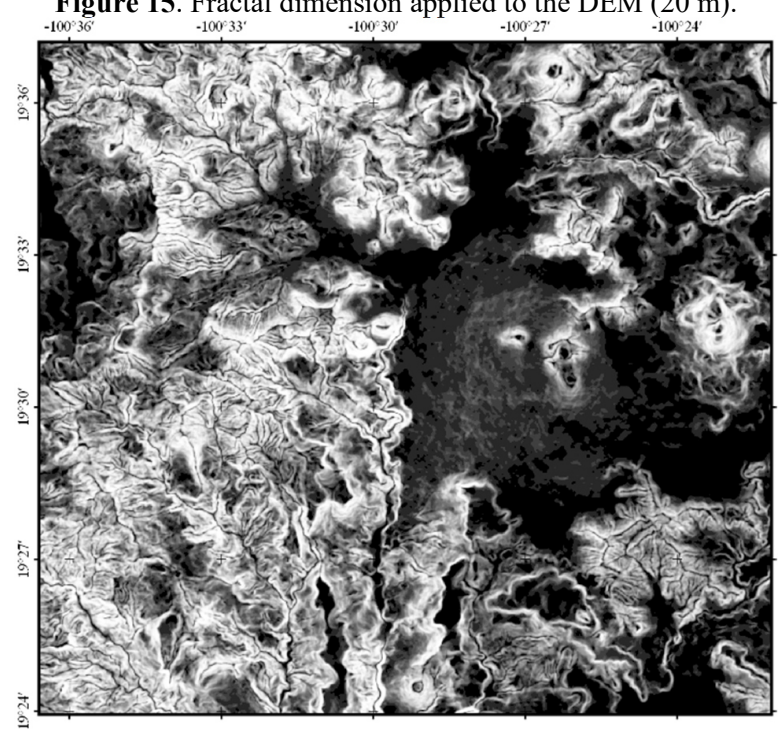

Surface 3D

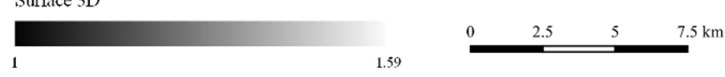

Figure 16. Three-dimensional surface measured in a 9 ha moving window (20 $\mathrm{m}$ resolution DEM).

The main contribution of the method presented in this article concerns the characterization of roughness at the local level, differentiating negative irregularities from positive irregularities, which allows to see the real weight of the structures in the relief In terms of applications, this roughness variable allows detailed classification of landscapes (crest, riverbeds, volcanic domes) as well as its associated processes.

\section{REFERENCES}

Aharonson O., Zuber M.T., Neumann G.A., Head J.W. 1998. Mars: northern hemisphere slopes and slope distributions. Geophys. Res. Lett. 25: 4413-4416. doi.org/10.1029/1998GL900057
Barnett, P.J., Singhroy, V.H., Shirota, J., Leney, S.J. 2004. Methods for remote engineering geology terrain analysis in boreal forest regions of Ontario, Canada. Environmental \& Engineering Geoscience, 10: 229-241.

Berti, M., Corsini, A., Daehne, A., 2013. Comparative analysis of surface roughness algorithms for the identification of active landslides. Geomorphology, 182: 1-18. doi.org/10.1016/j.geomorph.2012.10.022

Bingham, R., Siegert, M. 2009. Quantifying subglacial bed roughness in Antarctica: Implications for ice-sheet dynamics and history. Quaternary Science Reviews, 28, 223-236. doi.org/10.1016/j.quascirev.2008.10.014

Blatter, D.L., Carmichael, I.S.E., 1998. Plagioclase-free andesites from Zitácuaro (Michoacán), Mexico; petrology and experimental constraints. Contributions to Mineralogy and Petrology, 132, 121-138. doi.org/10.1007/s004100050411

Cao, W., Cai, Z., Tang, Z. 2015. Lunar surface roughness based on multiscale morphological method. Planetary and Space Science, 108, 13-23. doi.org/10.1016/j.pss.2014.09.009

Cloude, S.R., 1999. Eigenvalue parameters for surface roughness studies. Proc. SPIE 3754, Polarization: Measurement, Analysis and Remote Sensing II. doi.org/10.1117/12.366317

Cloude, S.R., Papathanassiou, K., Hajnsek, I., 2000. An Eigenvector Method for the Extraction of Surface Parameters in Polarmetric SAR. In: R.A. Harris and L. Ouwehand. SAR workshop: CEOS Committee on Earth Observation Satellites, European Space Agency, ESA-SP, Vol. 450, p. 693

De Reu, J., Bourgeois, J., Bats, M., Zwertvaegher, A., Gelorini, V., De Smedt, P., Chu, W., Antrop, M., De Maeyer, P., Finke, P., Van Meirvenne, M., Verniers, J., Crombé, P., 2013. Application of the topographic position index to heterogeneous landscapes. Geomorphology, 186, 39-49.

doi.org/10.1016/j.geomorph.2012.12.015

Evans, I.S. 1972. General geomorphometry, derivatives of altitude, and descriptive statistics. In: R.J. Chorley, Spatial Analysis in Geomorphology, Harper \& Row, 17-90.

Grohmann, C.H., Smith, M.J., Riccomini, C. 2011. Multiscale analysis of topographic surface roughness in the Midland Valley, Scotland. IEEE Transactions on Geoscience and Remote Sensing, 49(4), 1200-1213. doi.org/ 10.1109/TGRS.2010.2053546

Grohmann C.H., Hargitai H. 2014. Surface Roughness. In: Encyclopedia of Planetary Landforms. Springer, New York, NY. doi.org/10.1007/978-1-4614-9213-9_633-1

Grohmann, C.H., 2015. Effects of spatial resolution on slope and aspect derivation for regional-scale analysis. Computers \& Geosciences, 77, 111-117. doi:10.1016/j.cageo.2015.02.003

Haneberg, W.C., Creighton, A.L., Medley, E.W., Jonas, D.A. 2005. Use of LiDAR to assess slope hazards at the Lihir gold mine, Papua New Guinea. In: O. Hungr, R. Fell, R. Couture, E. Eberhardt, Proceedings of International Conference on Landslide Risk Management, Vancouver, Canada, Supplementary CD. 
Hani, A.F.M., Sathyamoorthy, D., Asirvadam, V.S. 2011. A method for computation of surface roughness of digital elevation model terrains via multiscale analysis. Computers \& Geosciences, 37(2), 177-192.

doi.org/10.1016/j.cageo.2010.05.021

Hani, A.F.M., Sathyamoorthy, D., Asirvadam, V.S. 2012. Computing surface roughness of individual cells of digital elevation models via multiscale analysis. Computers \& Geosciences, 43, 137-146. doi.org/10.1016/j.cageo.2011.09.015

Herzfeld, U.C., Mayer, H., Feller, W., Mimler, M. 2000. Geostatistical analysis of glacier-roughness data. Annals of Glaciology, 30, 235-242. doi.org/10.3189/172756400781820769

Hobson, R.D. 1972. Surface roughness in topography: quantitative approach. In: R.J., Chorley, Spatial Analysis in Geomorphology, Methuer, London, 225-245.

Instituto Nacional de Estadística y Geografía (INEGI) 2015. Conjunto de datos vectoriales de información topográfica (E14A25, E14A35), escala 1:50,000, serie III.

Jenson, S.K., Domingue, J.O. 1988. Extracting topographic structure from digital elevation data for geographic information system analysis. Photogrammetric engineering and remote sensing, 54(11), 1593-1600.

Kreslavsky, M.A, Head J.W. 1999. Kilometer-scale slopes on Mars and their correlation with geologic units: initial results from Mars Orbiter Laser Altimeter (MOLA) data. J. Geophys. Res. 104(E9): 21911-21924. doi.org/10.1029/1999JE001051

Melelli, L., Vergari, F., Liucci, L., Del Monte, M. 2017. Geomorphodiversity index: Quantifying the diversity of landforms and physical landscape. Science of the Total Environment, 584, 701-714. 10.1016/j.scitotenv.2017.01.101

McLeod, R.G., 1989. Geology and tectonics of El Bosque area, Michoacán, Mexico. Master's thesis, Brigham Young University, Provo, Utah, $39 \mathrm{p}$.

Parrot, J.-F., 2007. Tri-dimensional parameterisation: an automated treatment to study the evolution of volcanic cones. Géomorphologie. 3, 37-47.

doi.org/10.4000/geomorphologie.2723

Parrot, J.-F, Ramírez-Núñez, C. 2020. Parámetros morfológicos de la cuenca del río Magdalena a partir de datos LiDAR y modelos digitales de elevación. Terra Digitalis, 4(1).

doi.org/10.22201/igg.25940694.2020.1.68

Petersen, M.D., 1989. Geology and tectonics of the Jungapeo, Michoacán, Mexico area and its relationship to the Mexican Volcanic Belt. Master's thesis, Brigham Young University, Provo, Utah, $26 \mathrm{p}$.

Servicio Geológico Mexicano (SGM) 1998. Carta GeológicoMinera Morelia E14-1. Mich., Edo. Méx., y Gto. Primera Edición, México.

Siebe, C., Goff, F., Armienta, M.A., Counce, D., Poreda, R., Chipera, S. 2007. Geology and hydrogeochemistry of the Jungapeo CO2-rich thermal springs, State of Michoacán, Mexico. Journal of volcanology and geothermal research, 163(1-4), 1-33. doi.org/10.1016/j.jvolgeores.2007.03.008
Tarboton, D.G. 1997. A new method for the determination of flow directions and upslope areas in grid digital elevation models. Water resources research, 33(2), 309-319. doi.org/10.1029/96WR03137

Taud, H., Parrot, J.-F., 2005. Measurement of DEM roughness using the local fractal dimension. Géomorphologie. 4: 327-338. doi.org/10.4000/geomorphologie.622

Taud, H., Parrot, J.-F., Alvarez, R., 1999. DEM generation by contour line dilation. Computers \& geosciences. 25(7), 775-783. doi.org/10.1016/S0098-3004(99)00019-9 